\title{
Clinical Characteristics and Prognostic Factors in Childhood Bacterial Meningitis: A Multicenter Study
}

\author{
Özden Türel' ${ }^{1}$, Canan Yıldııım², Yüksel Yılmaz², Sezer Külekçi ${ }^{3}$ Ferda Akdaş ${ }^{3}$, Mustafa Bakır ${ }^{1}$ \\ ${ }^{1}$ Department of Pediatrics, Section of Pediatric Infectious Diseases, Faculty of Medicine, Marmara University, Istanbul, Turkey \\ ${ }^{2}$ Department of Pediatrics, Section of Pediatric Neurology, Faculty of Medicine, Marmara University, İstanbul, Turkey \\ ${ }^{3}$ Department of Audiology, Faculty of Medicine, Marmara University, Istanbul, Turkey Istanbul, Turkey
}

\begin{abstract}
Objective: To evaluate clinical features and sequela in children with acute bacterial meningitis (ABM).
\end{abstract}

Study Design: Multicenter retrospective study.

Material and Methods: Study includes retrospective chart review of children hospitalised with ABM at 11 hospitals in istanbul during 2005 . Follow up visits were conducted for neurologic examination, hearing evaluation and neurodevelopmental tests.

Results: Two hundred and eighty three children were included in the study. Median age was 12 months and $68.6 \%$ of patients were male. Almost all patients had fever at presentation (97\%). Patients younger than 6 months tended to present with feeding difficulties (84\%), while patients older than 24 months were more likely to present with vomitting (93\%) and meningeal signs (84\%). Seizures were present in 65 (23\%) patients. $26 \%$ of patients were determined to have at least one major sequela. The most common sequelae were speech or language problems (14.5\%). 6 patients were severely disabled because of meningitis. Presence of focal neurologic signs at presentation and turbid cerebrospinal fluid appearance increased sequelae significantly. Childen under 24 months of age developed neurologic sequelae more commonly than older children.

Conclusion: Symptoms and signs were largely depending on the age of the patient. Speech or language problems were the most common sequelae following meningitis.

Key Words: Bacterial meningitis, children, signs and symptoms, sequelae

\section{Introduction}

Acute bacterial meningitis ( $A B M)$ is a serious illness which can lead to severe complications. Epidemiology of bacterial meningitis has changed greatly in parts of the world with wide spread vaccination in childhood against Haemophilus influenza type b (Hib), Neisseria meningitidis and Streptococcus pneumoniae (1). In addition, antibiotic treatment and good care facilities decreased the occurrence of complications substantially in developed countries but ABM continues to be an important cause of morbidity and mortality in children in developing world. The mortality rate is approximately $5 \%$, and the longterm morbidity, mainly consisting of persistent neurological sequelae, is $15 \%$ (2). Sensorineural hearing loss, seizures, motor problems, hydrocephalus and mental retardation, as well as more subtle outcomes like cognitive, academic and behavioral problems are observed in post-meningitis children $(2,3)$. The aim of the present study was to evaluate clinical features and complications in children hospitalised with $A B M$ before the routine use conjugate vaccines against $\mathrm{Hib}$ and $\mathrm{S}$. pneumoniae in Turkey.

\section{Material and Methods}

\section{Field site and study population}

Sentinel hospitals qualified for the treatment of children with meningitis in Istanbul were chosen. The study population included children $>1$ month to $\leq 5$ years of age with a diagnosis of bacterial meningitis. Patients with recurrent meningitis, post-traumatic meningitis and those with underlying illnesses were excluded from the study.

\section{Data sources}

A patient database was constructed in the year 2005 from hospital discharge databases including patient abstacts and pharmacy reports. Patient characteristics including age, sex, vaccination status, education of the mother; history including clinical symptoms, previous use of antibiotics (type, route and exposure time), admission time; presenting signs; laboratory findings; acute neurologic complications; treatment and outcome were noted.

\section{Case definition}

Both probable and confirmed bacterial meningitis cases according to World Health Organisation definition were included (4).

\section{Probable}

Presence of clinical findings such as fever, headache, meningeal irritation findings in accordance with cerebrospinal fluid (CSF) examination showing at least one of the following: turbid appearance; leukocytosis ( $>100$ cells $\left./ \mathrm{mm}^{3}\right)$; leukocytosis $\left(10->100\right.$ cells $\left./ \mathrm{mm}^{3}\right)$ and either an elevated protein $(>100$ $\mathrm{mg} / \mathrm{dL}$ ) or decreased glucose $(<40 \mathrm{mg} / \mathrm{dL})$.

Address for Correspondence: Dr. Özden Türel, Department of Pediatrics, Section of Pediatric Infectious Diseases, Faculty of Medicine, Bezmialem Vakıf University, İstanbul, Turkey, Phone: +902124531700 e-mail: oturel@bezmialem.edu.tr 


\section{Confirmed}

Laboratory-confirmed by growing (culture) or identifying (by Gram stain or antigen detection methods) a bacterial pathogen in the CSF or from the blood in a child with clinical syndrome consistent with bacterial meningitis.

\section{Assessment of sequela}

Follow up visits were conducted up to 24 months after discharge and patients were prospectively evaluated with neurologic examination, hearing evaluation and neurodevelopmental tests for development of neurologic sequelae.

\section{Hearing evaluation}

Screening was performed using transient evoked otoacoustic emissions (Echocheck Otodynamics, UK). The tympanometries were performed using impedance audiometer device (AT235 Interacoustic company, Denmark) and auditory brainstem responses (ABR) were obtained with $A B R$ device (Amplaid-Mk 15, USA).

\section{Neurodevelopmental assessment}

Denver Developmental Screening Test-Il test was used for evaluation for cognitive and behavioural problems (5). The subject's performance against the regular age was evaluated in four categories (social contact, fine motor skill, language, and gross motor skill. Two or more delay in any field or delay in more than one field was accepted as suspicious and the test was repeated one month later. Five or more delays in any field were accepted as abnormal.

\section{Data analysis}

All statistical analysis was performed with SPSS version 11.5 (SPSS Inc. Chicago, IL, USA). Mann-Whitney U Test, Pearson's chi-squared test and Fisher's exact test were used for evaluation of factors affecting development of sequela. A 2 -tailed $p$ value $<0.05$ was considered significant.

\section{Ethical issues}

This study was approved by the Research Ethical Committee of Marmara University School of Medicine. Permission for access to patient charts data was provided by both Turkish Ministry of Health and management of each hospital.

\section{Results}

A total of 283 children, 194 boys and 89 girls were included in the study. Age distribution of patients were as follows: 95 patients $(33.6 \%)>1$ months- 6 months old, 97 patients (34.3\%) 7-24 months old, 22 patients (7.8\%) 25-36 months old and 69 patients (24.4\%) 37-60 months old. Only 15 patients $(10 \%)$ had a history of vaccination with Hib conjugate vaccine. Parental education level was at the level of primary school in the majority of patients while about $10 \%$ of mothers had no formal education. $38 \%$ of patients had received antibiotics (70\% parenteral) prior to admission. $46.1 \%$ of patients were admitted within the $1^{\text {st }}$ day of beginning of symptoms. Duration of symptoms was 2-4 days, 5-7 days and longer than 7 days in $38.6 \%, 10.1 \%$ and $5 \%$ of patients respectively. Clini- cal manifestations included fever (97.5\%), vomitting (45.5\%), lethargy $(24 \%)$, seizures (23\%), petechial rash $(10 \%)$ and focal neurologic signs (5\%). Bulging fontanelle was present in $55 \%$ of patients under 6 months and meningeal signs were present in $84 \%$ of patients over 24 months of age. An etiological organism could be identified in 33 patients. Most common organisms were Hib (36.3\%), S. pneumonia (30.3\%) and $\mathrm{N}$. meningitidis (21\%). Two hundred thirty seven (92.6\%) received third generation cephalosporins (alone or in combination with other antibiotics) for treatment. One hundred seventeen patients (43\%) received dexamethasone as adjunctive therapy. Seven patients were transferred to intensive care units. Two patients died: Both male, a 5 months old patient with meningococcemia and a 9 months old patient with negative CSF and blood cultures.

Thirty eight patients (13.4\%) developed neurologic complications (Table 1). Hydrocephalus was detected in 17 patients. Following discharge, 146 patients could be evaluated for assessment of sequela and $38(26 \%)$ were determined to have at least one sequela. The most common sequelae were speech or language problems (14.5\%). Abnormalities of fine motor skill, gross motor skill and social contact were other pathologies detected by Denver test. Sensorineural hearing loss was detected in $11(7.6 \%)$ patients. Almost all of the patients with hearing defects had also neuromotor or developmental delay. Six patients were severely disabled because of meningitis. One patient with quadriparesis had also total loss of visual activity. Factors such as mothers' educational level; previous use of antibiotics; duration of symptoms before admission; presence of petechial rash; presence of convulsions; prolonged convulsions, peripheral blood leukocyte count; CSF leukocyte count, CSF glucose level or CSF protein level; treatment with ceftriaxone or receipt of dexamethasone did not differ significantly between patients with sequelae or those without sequelae. Presence of focal neurologic signs at presentation and turbid CSF appearance increased sequelae development significantly (Table 2).

\section{Discussion}

Bacterial meningitis continues to be an important cause of neurologic sequelae despite advances in antimicrobial therapy

Table 1. Neurologic complications of patients with bacterial meningitis

\begin{tabular}{|lcc|}
\hline Variable & $\mathbf{n}$ & $\%$ \\
\hline Subdural effusion & 27 & 9.5 \\
Hydrocephaly & 17 & 5.7 \\
Prolonged seizures & 14 & 4.9 \\
Subdural empyema & 6 & 2.1 \\
Abduscens paralysis & 2 & 0.7 \\
Ataxia & 2 & 0.7 \\
Cerebral edema & 1 & 0.4 \\
Sinus vein thrombosis & 1 & 0.4 \\
\hline
\end{tabular}


Table 2. Relation of Clinical and Laboratory findings with development of sequela

\begin{tabular}{|c|c|c|c|}
\hline Variable & $\begin{array}{c}\text { No sequela } \\
n\end{array}$ & $\begin{array}{c}\text { Sequela } \\
n\end{array}$ & ${ }^{*} p$ \\
\hline \multicolumn{4}{|l|}{ Sex } \\
\hline Female & 29 & 11 & 0.803 \\
\hline Male & 79 & 27 & \\
\hline \multicolumn{4}{|l|}{ Age (months) } \\
\hline $1-24$ & 76 & 33 & 0.045 \\
\hline $25-60$ & 32 & 5 & \\
\hline \multicolumn{4}{|l|}{ Petechial rash } \\
\hline Negative & 31 & 11 & 0.710 \\
\hline Positive & 11 & 2 & \\
\hline \multicolumn{4}{|l|}{ Seizure } \\
\hline Negative & 32 & 11 & 0.088 \\
\hline Positive & 19 & 15 & \\
\hline \multicolumn{4}{|l|}{ Lethargy } \\
\hline Negative & 22 & 5 & 0.071 \\
\hline Positive & 23 & 15 & \\
\hline \multicolumn{4}{|l|}{ Previous antibiotic use } \\
\hline Negative & 65 & 22 & 0.890 \\
\hline Positive & 42 & 15 & \\
\hline \multicolumn{4}{|l|}{ Focal neurologic sign } \\
\hline Negative & 95 & 27 & 0.001 \\
\hline Positive & 2 & 8 & \\
\hline \multicolumn{4}{|l|}{ CSF appearance } \\
\hline Clear & 66 & 13 & 0.002 \\
\hline Turbid & 21 & 16 & \\
\hline CSF protein* & $98.97 \pm 125.74$ & $139.81 \pm 152.61$ & 0.687 \\
\hline CSF leukocyte count* & $393 \pm 370$ & $513 \pm 441$ & 0.208 \\
\hline $\begin{array}{l}\text { CSF leukocyte count } \\
\text { in } 2^{\text {nd }} L^{*}\end{array}$ & $93 \pm 86$ & $84 \pm 72$ & 0.931 \\
\hline \multicolumn{4}{|l|}{ Dexamethasone use } \\
\hline No & 42 & 21 & 0.076 \\
\hline Yes & 60 & 15 & \\
\hline
\end{tabular}

*Mean \pm SD

The $p$ value $<0.05$ indicates a significant difference between groups (two tailed $p$ value by Pearson chi square, Fisher's exact test or Student's t test as appropriate)

CSF: Cerebrospinal fluid

$(2,3)$. The clinical data gathetered in our study represents a detailed work to evaluate a significant number of patients. It is as representative as possible since it includes 11 major hospitals in İstanbul. Since it was conducted before the introduc- tion of Hib vaccine (2006) and pneumococcal vaccine (2009) in routine childhood vaccination programme in Turkey, this study will aid in comparison of features in the post vaccine era.

Low socioeconomic conditions and male sex are reported to increase the risk of acquiring meningitis (6). $68 \%$ of our patients were male and majority of parents had low educational levels. During the study period Hib vaccine was available in private market but about $90 \%$ of children had not received the vaccine which shows that private practice has a minor role in vaccination of children in Turkey. The median age of patients was 12 months similar to previous reports in the prevaccine era $(7,8)$. About half of patients had attended to hospital during the first 24 hours of symptoms. Inspite of low educational level of parents, this shows increased awareness of symptoms of disease by parents and good health care facilities in Istanbul.

Clinical manifestations of bacterial meningitis are nonspesific and no single sign is pathognomonic $(9,10)$. Classic triad of fever, neck stiffness and an altered mental status is low among adults and even lower in children (11). Bulging fontanelle is neither sensitive nor spesific (12). Meningeal signs are usually positive in $60-80 \%$ of patients (13). Symptoms and signs of our patients largely depended on the age of the patient. Fever was present in $97 \%$ of patients with similar frequency in all age groups. Apart from fever, the most common findings in infants were lethargy, poor feeding and bulging fontanelle. Older children more likely presented with headache, vomitting and meningeal signs. Seizures were present in $23 \%$ of patients. Seizures are reported in about $30 \%$ of children with meningitis at presentation $(2,14)$. In a study of 410 children with bacterial meningitis, $27 \%$ had seizures but all had other signs such as altered consciousness, nuchal rigidity or petechial rash (15).

Neurologic complications can develop at any time during the course of bacterial meningitis. Collection of fluid in the subdural space can be demonstrated in as many as $50 \%$ of children during acute illness. Hydrocephalus that develops beyond the newborn period is an uncommon complication of meningitis (2). We detected subdural effusions in 27 out of 111 patients undergoing neuroimaging and hydrocephaly was present in 17 patients. With follow up visits up to 24 months after discharge $26 \%$ of patients were determined to have at least one sequela which is compatible with the range of 8 to $37 \%$ in literature $(3,16)$. The most common sequelae were speech or language problems (14.5\%). In a study evaluating long term (12 years after meningitis) effects of meningitis, patients functioned at significantly lower levels for intelligence measurements, high level neuropsychological skills and had more behavioural difficulties at home and at school compared with controls (17). Kirimi et al. (18) detected hydrocephalus (12.5\%), cerebral palsy, hemiparesis, hemiplegia and strabismus as major neurologic sequela in children with purulent meningitis. Neuromotor disabilities (11.8\%) and hearing loss (7.6\%) were also substantial in our patients. Hearing evaluation should be done at or soon after discharge. Only one fourth of parents declared that they had been informed by physicians for hearing evaluation at discharge. However in the largest cohort since the 1980s, hearing loss developed in 7 percent of cases, one-quarter of which were detected after the routine follow-up period had ended (19). 
Factors related to the outcome of bacterial meningitis in children include age at the time of diagnosis, course or progression of disease before antibiotic therapy is effective, etiologic agent, the number of organisms or the quantity of polysaccharide material present in the meninges and delayed sterilization of the CSF $(2,20-23)$. We found that children under 24 months of age developed neurologic sequela more commonly than older children. In a previous study, onset of meningitis before 12 months of age was significantly associated with decreased performance on tests requiring language and executive skills (20). Since the number of bacteriologically confirmed cases were too small, an etiological comparison could not be done. Level of consciousness at the time of admission, prolonged or complicated seizures and low CSF glucose are also reported among factors affecting outcome $(24,25)$. Focal neurologic findings at the time of admission proved to be the most reliable predictor of permanent sequela of bacterial meningitis (26). The patients who were obdunted at presentation developed significant neurologic sequela in our study. Focal signs at admission and turbid CSF appearance also increased sequelae significantly. All the patients with focal neurologic signs at presentation were younger than 2 years of age. 9 out of 17 patients with hydrocephalus could be evaluated for development of sequela and all were were found to have one or more sequela. A cochrane review concluded that corticosteroids significantly reduced hearing loss and neurological sequelae in high-income countries (27). Use of corticosteroids did not affect sequela development in our study. A recent randomized double-blind, clinical trial, revealed no significant relief in hearing impairment by adjuvant intravenous dexamethasone (28). Instead, the child's presenting status and age were the most important predictors of hearing loss.

Intellectual and behavioral deficits, particularly speech or language problems, are the most common sequelae following meningitis. Early identification and intervention may help to minimize long-term impact of these problems.

Ethics Committee Approval: Ethics committee approval was received for this study.

\section{Informed Consent: N/A}

Peer-review: Externally peer-reviewed.

Author contributions: Concept - Ö.T., M.B.; Design - Ö.T., M.B.; Supervision - M.B., F.A.; Resource - M.B., F.A.; Materials - Ö.T., C.Y., Y.Y., S.K.; Data Collection\&/or Processing - Ö.T., M.B.; Analysis\&/or Interpretation - Ö.T., M.B.; Literature Search - Ö.T., M.B.; Writing - Ö.T., M.B.; Critical Reviews - Ö.T., C.Y., Y.Y., S.K., F.A., M.B.

Acknowledgements: The authors acknowledge colleagues from participating institutions: Bezmialem Vakıf Guraba Training and Research Hospital, Zeynep Kamil Training and Research Hospital, Bakırköy Maternity and Children Training and Research Hospital, Haseki Training and Research Hospital, Haydarpaşa Numune Training and Research Hospital, Şişli Etfal Training and Research Hospital, Kartal Lütfi Kırdar Training and Research Hospital, Göztepe Training and Research Hospital, Okmeydanı Training and Research Hospital, Cerrahpaşa Medical Faculty Hospital and Marmara University Hospital.

Conflict of Interest: No conflict of interest was declared by the authors.

Financial Disclosure: No financial disclosure was declared by the authors.

\section{References}

1. Thigpen MC, Whitney CG, Messonnier NE, Zell ER, Lynfield R, Hadler JL, et al. Bacterial meningitis in the United States, 19982007. N Engl J Med 2011;364:2016-25. [CrossRef]

2. Feigin RD, Pearlman E. Bacterial meningitis beyond the neonatal period. In: Feigin RD, Demler GJ, Cherry JD, Kaplan SL, editors. Textbook of pediatric infectious diseases. 5th ed. Philadelphia: Saunders; 2004:443-74.

3. Chandran A, Herbert H, Misurski D, Santosham M. Long-term sequelae of childhood bacterial meningitis:an underappreciated problem. Pediatr Infect Dis J 2011;30:3-6. [CrossRef]

4. World Health Organization (WHO). WHO report of the technical review group meeting, Global program for vaccines and Immunizations. Vaccine research and Development. Geneva, Switzerland: WHO;1998.

5. Frankenburg WK, Dodds J, Archer P, Shapiro H, Bresnick B. The Denver II:a major revision and restandardization of the Denver Developmental Screening Test. Pediatrics 1992;89:91-7.

6. Scheld WM. Bacterial meningitis in the patient at risk:intrinsic risk factors and host defense mechanisms. Am J Med 1984;76:193-207. [CrossRef]

7. Somer A, Yalçın I, Salman N, Ones U, Guler N, Kaygusuz A. Pneumococcal meningitis in children:Evaluation of 46 cases. Flora 1999;4:107-13.

8. Aygun AD, Sen CEN, Aydınoglu AH, Yılmaz E, Tutunculer F, Akarsu $A$, et al. [Childhood meningitis in a regional medical center in Elazığ]. Çocuk Sağlığı ve Hastalıkları Derg 2001;44:141-8.

9. Feigin RD, McCracken GH Jr, Klein JO. Diagnosis and management of meningitis. Pediatr Infect Dis J 1992;11:785-814. [CrossRef]

10. Curtis S, Stobart K, Vandermeer B, Simel DL, Klassen T. Clinical features suggestive of meningitis in children:a systematic review of prospective data. Pediatrics 2010;12:952-60. [CrossRef]

11. Van de Beek D, de Gans J, Spanjaard L, Weisfelt M, Reitsma JB, Vermeulen M. Clinical features and prognostic factors in adults with bacterial meningitis. N Engl J Med 2004;351:1849-59. [CrossRef]

12. Levy M, Wong E, Fried D. Diseases that mimic meningitis. Analysis of 650 lumbar punctures. Clin Pediatr (Phila) 1990;29:254-61. [CrossRef]

13. Kaplan SL. Clinical presentations, diagnosis and prognostic factors of bacterial meningitis. Infect Dis Clin North Am 1999;3:579-94. [CrossRef]

14. Arditi M, Mason EO Jr, Bradley JS, Tan TQ, Barson WJ, Schutze $\mathrm{GE}$, et al. Three year multicenter surveillance of pneumococcal meningitis in children. Clinical characteristics and outcome related to penicillin susceptibility and dexamethasone use. Pediatrics 1998;102:1087-97. [CrossRef]

15. Green SM, Rothrock SG, Clem KJ, Zurcher RF, Mellick L. Can seizures be the sole manifestation of meningitis in febrile children? Pediatrics 1993;92:527-34.

16. Baraff LJ, Lee SI, Schriger DL. Outcomes of bacterial meningitis in children:a meta-analysis. Pediatr Infect Dis J 1993;12:389-94. [CrossRef]

17. Grimwood K, Anderson VA, Bond L, Catroppa C, Hore RL, Keir $\mathrm{EH}$, et al. Adverse outcomes of bacterial meningitis in school-age survivors. Pediatrics 1995;95:646-56.

18. Kirimi $E$, Tuncer $O$, Arslan $S$, Ataş B, Caksen $H$, Uner $A$, et al. Prognostic factors in children with purulent meningitis in Turkey. Acta Med Okayama 2003;57:39-44.

19. Koomen I, Grobbee DE, Roord JJ, Donders R, Jennekens-Schinkel A, van Furth AM. Hearing loss at school age in survivors of bacterial meningitis:assessment, incidence, and prediction. Pediatrics 2003;112:1049-53. [CrossRef]

20. Anderson V, Bond L, Catroppa C, Grimwood K, Keir E, Nolan T. Childhood bacterial meningitis:impact of age at illness and acute medical complications on long term outcome. J Int Neuropsychol Soc 1997;3:147-58. 
21. Kilpi T, Anttila M, Kallio MJ, Peltola H. Severity of childhood bacterial meningitis and duration of illness before diagnosis. Lancet 1991;338:406-9. [CrossRef]

22. Feldman WE. Concentrations of bacteria in cerebrospinal fluid of patients with bacterial meningitis. J Pediatr 1976;88:549-52. [CrossRef]

23. Lebel $\mathrm{MH}$, McCracken GH. Delayed cerebrospinal fluid sterilization and adverse outcome of bacterial meningitis in infants and children. Pediatrics 1989;83:161-7.

24. Chavez-Bueno S, McCracken G. Bacterial meningitis in children. Pediatr Clin N Am 2005;52:795-810. [CrossRef]
25. Fortnum HM. Hearing impairment after bacterial meningitis: $A$ review. Arch Dis Child 1992;67:1228-33. [CrossRef]

26. Pomeroy SL, Holmes SJ, Dodge PR, Feigin RD. Seizures and other neurologic sequelae of bacterial meningitis in children. $\mathrm{N}$ Engl J Med 1990;323:1651-7. [CrossRef]

27. Brouwer MC, Mclntyre P, de Gans J, Prasad K, van de Beek D. Corticosteroids for acute bacterial meningitis. Cochrane Database Syst Rev 2010;8:CD004405.

28. Peltola H, Roine I, Fernández J, González Mata A, Zavala I, Gonzalez Ayala $S$, et al. Hearing impairment in childhood bacterial meningitis is little relieved by dexamethasone or glycerol. Pediatrics 2010;125:e1-8. [CrossRef] 